\title{
Application of the artificial neural networks for identification of polymers on the basis of their flammability*)
}

\author{
Małgorzata Rabiej ${ }^{1)}$ \\ DOI: dx.doi.org/10.14314/polimery.2020.9.3
}

\begin{abstract}
The work presents the structure and principle of operation of the artificial neuron network constructed for identification of a polymer on the basis of its flammability. The characteristic properties of burning of a polymer are saved in a special form in a database. The network creates a binary standard for each polymer from the database, coding data by means of the signals of the values $1,0,-1$. The network memorizes data related to each polymer detecting the similarities and differences between them and determines the weights which reflect the importance of particular features of its burning process.
\end{abstract}

Keywords: identification of polymers, artificial neural networks, test of flammability, oxygen index.

\section{Zastosowanie sztucznych sieci neuronowych do identyfikacji polimerów na podstawie ich palności}

Streszczenie: Przedstawiono strukturę i zasadę działania sztucznej sieci neuronowej skonstruowanej do identyfikacji polimeru na podstawie jego palności. Charakterystyczne cechy palności każdego polimeru zostały zapisane we wzorcowej bazie danych. Dla każdego polimeru z tej bazy sieć tworzy wzorzec binarny, w którym charakterystyczne cechy palności są kodowane jako sygnały o wartościach -1, 0 i 1. Sieć zapamiętuje palność każdego polimeru, wykrywając podobieństwa i różnice między nimi oraz określając wagi odzwierciedlające znaczenie poszczególnych cech palności.

Słowa kluczowe: identyfikacja polimerów, sieć neuronowa, test palności, wskaźnik tlenowy.

Polymers can be identified on the basis of their different features like physical appearance, flammability, density, thermal properties, spectroscopic properties, etc. Many various methods are used to this aim: Differential Scanning Calorimetry (DSC), Fourier Transform Infrared spectroscopy (FT-IR), Near Infrared (NIR) and Ultraviolet (UV) spectroscopy, Nuclear Magnetic Resonance (NMR) spectroscopy, X-ray Diffraction (XRD), etc.

One of the well-known methods of polymer identification is the test of flammability.

A polymer is identified on the basis of its behavior in fire, emitted smoke, smell and the appearance of ashes. The flammability tests determine such features of a polymer burning behavior like the type of burning (burns headily, burns, incandesces, does not burn), type of flame, colour or arrangement of colours in a flame, colour and smell of smoke, behavior in a flame (sparking, appearance of blisters, melting, dripping, charring),

\footnotetext{
1) University of Bielsko-Biala, Faculty of Materials, Civil and Environmental Engineering, Willowa 2, 43-309 Bielsko-Biała, Poland.

e-mail: mrabiej@ath.bielsko.pl

*) Material contained in this article was presented at the XI International Conference on "X-ray Investigations of Polymer Structure", 3-6 December 2019, Ustroń, Poland.
}

smell of smoke emitted after snuffing out, $\mathrm{pH}$ of fume emitted after snuffing out. Finally - the residues of burning are evaluated [1-4]. The behavior of a polymer during burning depends on several factors. Among other things, one can enumerate its chemical composition, molecular structure, supermolecular structure, physical parameters like density, porosity, shape of a sample, etc.

Theoretically each polymer should burn in different way. However the differences in the flammability of various polymers may be very subtle and difficult to detect. In such cases additional investigations like determination of the solubility in various solvents or measurement of the Limiting Oxygen Index (LOI) [5, 6] may be necessary to identify the polymer.

The limiting oxygen index is defined as the minimum fraction of oxygen in a mixture of oxygen and nitrogen that will just support combustion (after ignition). The test is performed under standardized conditions, at $25^{\circ} \mathrm{C}$. The higher the LOI of a polymer material, the lower the heat flux provided by its flame and the higher the flammability resistance. The LOI test, does not reproduce a realistic fire environment; it is thus mainly used to compare the relative flammability and rank polymer and composite materials. For instance it is used in evaluation of the influence of modifications of a given material like the addition of different fillers, plasticizers, etc. on its flammability and the 
effectivity of different flame retardants. Based on the $L O I$ all materials are divided into 3 flammability classes $[5,6]$ :

- flammable $(L O I<21)$,

- combustible $(21<L O I<28)$,

- non-flammable, melts at high temperature LOI >28.

The identification of a polymer by means of the flammability tests consists in a comparison of its properties determined in the test with the properties of polymers saved in databases. Such searching in the database may be tedious and not always effective.

In this work a new, original algorithm of polymer identification on the basis of their flammability is presented. The algorithm belongs to the well-known group of artificial intelligence methods: the Artificial Neural Networks (ANN) [7-12]. The artificial neural networks are constructed in imitation of real biological nervous systems. For this reason their functioning is described using a specific biological terminology.

In the elaborated ANN, the information on the flammability and on the LOI of polymers are coded in a special way in a database. The network creates digital standards for each polymer constructed as chains of signals with the values of 1,0 and -1 .

A digital standard contains information on the most important flammability properties of a given polymer and simultaneously it is unique enough to be different for different polymers. The network finds such a polymer in the database the properties of which are most similar to those ones of the polymer which is to be recognized.

The ANN networks are employed for solving various tasks when it is difficult to construct an algorithm of their accomplishing, when the data are incomplete or imprecise, when the course of investigated phenomenon is non-linear, etc. For instance they are used for pattern and speech recognition, data classification, forecasting, etc.

There are several topical works presenting applications of the ANN for detection of short circuits, electrical damages and defects as well as for testing materials of required mechanical, electrical and burning properties [13-15].

The structure and working scheme of a neural network depend on the type of task it has to accomplish. Each kind of neural network uses a specific learning algorithm and can be employed only for well-defined tasks.

Performed tests have shown that the ANN described in this work is fast, effective and can be easily employed in practical applications.

\section{THE ARTIFICIAL NEURAL NETWORKS}

ANN are based on a very simplified model of a real biological nervous system [7-12].

An artificial neural network is formed by a set of artificial neurons. Main function of neurons, is transmitting and transforming signals (information) to other neurons. A neuron may receive one or more input signals which are transformed to produce one output signal. Each signal is introduced into a neuron with a specific weight. The weight increases or decreases the strength of the signal. A neural network modifies the weights so as the weight of each signal corresponds to its real importance. The process of weights determination is called learning. Learning involves adjusting the weights of the network to improve the accuracy of the result of its work. The weights found in the learning process form a memory of the neural network. For each neuron a total activation signal is calculated as the sum of weighted input signals net of the optional threshold value. The total activation signal is transformed by means of activation function into an output signal.

Typically, neural networks are organized in layers. Different layers may perform different tasks. Each network consists of two layers at least: input and output ones. The input layer serves for data introduction. Number of input signals is equal to the number of parameters describing an object. The output layer contains signals which are the solution of performed task.

\section{STRUCTURE OF THE NEURAL NETWORK}

The identification of a polymer on the basis of its burning properties consists in a comparison of these properties with the properties of various polymers saved in a data base and employed as standards. So at first a database containing standards for all polymers which are to be recognized must be created. The database should contain only one standard for a given polymer. The database of standards used in this network has been created based on the literature data [1-6].

The network for polymer identification has a twolayer structure. The input layer of the network contains as many neurons as many properties are investigated. For each polymer in the database a digital standard is formed in the shape of a chain of signals with the values of $1,0,-1$. The value of each signal in the chain inform on some characteristic property of burning of a given polymer. A digital standard contains information on the most important features of given polymer and simultaneously it is unique enough to be different for different polymers.

When the digital standards for all polymers are constructed, the weights related to each signal are established. The weights reflect the importance of particular property of burning behavior for identification of a given polymer and they form the memory of the neural network. When the weights are established for each signal of each digital standard, the network is ready to work.

The algorithm described in this work is a fully original solution elaborated as a separate computer program using the Object Pascal programming language.

\section{Construction of a database}

First step in constructing the ANN consists in creation of a database containing coded information on the polymers employed as standards. The coding aims at minimi- 
$\mathrm{T}$ a $\mathrm{b}$ l e 1. Database with coded information on the polymers employed as standards

\begin{tabular}{|c|c|c|c|c|c|c|c|c|c|c|c|c|c|c|c|c|c|}
\hline \multirow[t]{2}{*}{ Symbol } & \multirow[t]{2}{*}{ Polymer } & 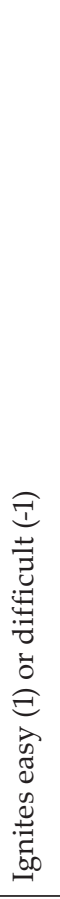 & 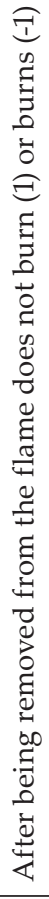 & 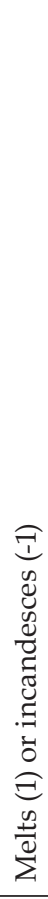 & 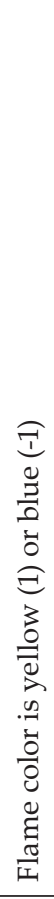 & 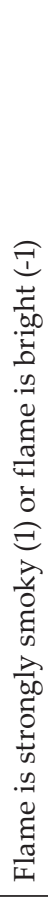 & 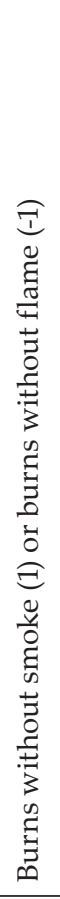 & 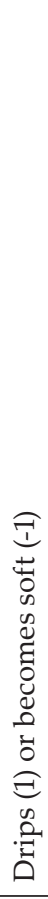 & 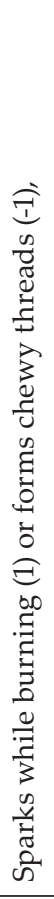 & 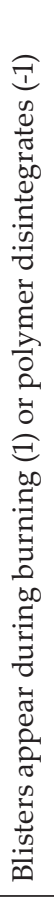 & 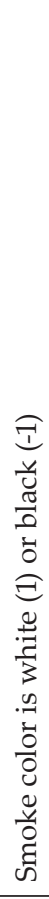 & 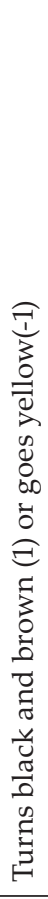 & 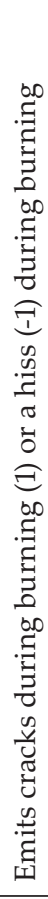 & 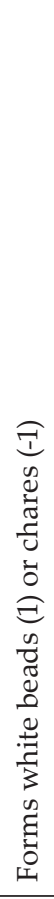 & 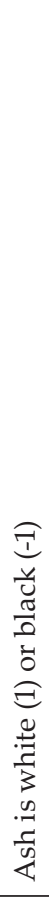 & $\begin{array}{l}\bar{\Xi} \\
\text { है }\end{array}$ & $\widetilde{1}$ \\
\hline & & 1 & 2 & 3 & 4 & 5 & 6 & 7 & 8 & 9 & 10 & 11 & 12 & 13 & 14 & 15 & 16 \\
\hline CA & Cellulose acetate & -1 & 1 & & & -1 & & 1 & 1 & & & & 1 & 1 & & 8 & 18 \\
\hline $\mathrm{Ce}$ & Cellulose & 1 & -1 & 1 & 1 & & & 1 & 1 & & & & & & & 0 & 19 \\
\hline Cotton & Cotton & 1 & 1 & & & & & & 1 & & 1 & & & & 1 & 0 & 17 \\
\hline PA & Polyamide & -1 & -1 & & -1 & -1 & & 1 & -1 & 1 & & & 1 & 1 & & 1 & 24 \\
\hline PAN & Polyacrylonitrile & 1 & 1 & 1 & & & & & & -1 & & & & & & & 27 \\
\hline PC & Polycarbonate & 1 & 1 & 1 & & 1 & & -1 & 1 & 1 & & & 1 & -1 & 1 & 6 & 26 \\
\hline PE & Polyethylene & 1 & -1 & 1 & -1 & -1 & & 1 & & & & & & & & 4 & 18 \\
\hline PET & $\begin{array}{l}\begin{array}{l}\text { Poly(ethylene } \\
\text { terephthalate) }\end{array} \\
\end{array}$ & -1 & 1 & & 1 & 1 & & & 1 & -1 & -1 & -1 & & & & 3 & 21 \\
\hline PI & Polyimide & & & -1 & & & & & & & & & & & & 5 & 47 \\
\hline PLA & Polylactide & 1 & -1 & & & & 1 & 1 & & & & & & & & & 20 \\
\hline PMMA & $\begin{array}{l}\text { Poly(methyl } \\
\text { methacrylate) }\end{array}$ & & -1 & & & 1 & & -1 & & -1 & & & 1 & & & 2 & 18 \\
\hline POM & Polyoxymethylene & 1 & -1 & & & & -1 & & & & & & & & & & 18 \\
\hline PP & Polypropylene & 1 & -1 & 1 & -1 & -1 & & 1 & & & & & & & & 4 & 18 \\
\hline PS & Polystyrene & 1 & -1 & 1 & 1 & 1 & & -1 & & & -1 & 1 & & & & 3 & 17 \\
\hline PTFE & Polytetrafluoroethylene & -1 & & & & & & & & & 1 & & & & & & 95 \\
\hline PU & Polyurethane & -1 & -1 & & 1 & -1 & & 1 & & & 1 & & & -1 & & 7 & 20 \\
\hline PVA & Poly(vinyl alcohol) & 1 & -1 & & & & & 1 & & & & & & & 1 & 7 & 22 \\
\hline PVC & Poly(vinyl chloride) & -1 & 1 & & 1 & 1 & & & 1 & -1 & 1 & 1 & & & 1 & 5 & 42 \\
\hline PVDC & Poly(vinylidene chloride) & -1 & 1 & & & & & & & & & & & & & 2 & 60 \\
\hline PVDF & Poly(vinylidene fluoride) & -1 & -1 & 1 & & & & 1 & & & & & & & & 7 & 44 \\
\hline Silk & Silk & -1 & 1 & -1 & & & & & & & & & 1 & 1 & 1 & 1 & 18 \\
\hline WO & Wool & -1 & 1 & -1 & -1 & & & & & & -1 & & & 1 & & 1 & 24 \\
\hline
\end{tabular}

zation of the number of data loaded into the network and simultaneously at saving the most important information on the flammability of the standards. The database is created as a two-dimensional table (Table 1). According to the requirements of the elaborated $\mathrm{ANN}$, a specific structure of data and the method of their coding have been proposed. Each row of the table is related to one polymer while the 16 columns contain numbers (codes) informing on the occurrence of specific properties of the burning process. The set of considered properties that 
are characteristic for burning of different polymers have been selected and elaborated on the basis of the literature data [1-6]. The numbers in the first 14 columns may have two values: 1 or -1 according to the following rules:

\begin{tabular}{|c|c|}
\hline Column & $\begin{array}{l}\text { Property of the burning process of } \\
\text { a polymer }\end{array}$ \\
\hline 1 & Ignites easy (1) or difficult (-1) \\
\hline 2 & $\begin{array}{l}\text { After being removed from the flame } \\
\text { does not burn (1) or burns }(-1)\end{array}$ \\
\hline 3 & Melts (1) or incandesces (-1) \\
\hline 4 & Flame color is yellow (1) or blue $(-1)$ \\
\hline 5 & $\begin{array}{c}\text { Flame is strongly smoky (1) or flame is } \\
\text { bright }(-1)\end{array}$ \\
\hline 6 & $\begin{array}{l}\text { Burns without smoke (1) or burns } \\
\text { without flame (-1) }\end{array}$ \\
\hline 7 & Drips (1) or becomes soft $(-1)$ \\
\hline 8 & $\begin{array}{l}\text { Sparks while burning (1) or forms } \\
\text { chewy threads }(-1)\end{array}$ \\
\hline 9 & $\begin{array}{l}\text { Blisters appear during burning (1) or } \\
\text { polymer disintegrates }(-1)\end{array}$ \\
\hline 10 & Smoke color is white (1) or black (-1) \\
\hline 11 & $\begin{array}{l}\text { Turns black and brown (1) or goes yel- } \\
\qquad \text { low (-1) }\end{array}$ \\
\hline 12 & $\begin{array}{c}\text { Emits cracks }(1) \text { or a hiss }(-1) \text { during } \\
\text { burning }\end{array}$ \\
\hline 13 & Forms white beads (1) or chares (-1) \\
\hline 14 & Ash is white (1) or black (-1) \\
\hline
\end{tabular}

Column № 15 informs on the smell emitted during burning. The smell is coded by means of nine numbers in the following way:

\begin{tabular}{c|c}
\hline Smell & Number \\
\hline Roasted paper & 0 \\
Roasted protein & 1 \\
Fruity & 2 \\
Floral & 3 \\
Paraffin & 4 \\
Hydrogen chloride & 5 \\
Phenol & 6 \\
Hardcore, nasty & 7 \\
Acetic acid & 8 \\
\hline
\end{tabular}

Column № 16 contains the value of LOI

Table 1 presents the database created for the elaborated neural network containing information on 22 polymers.

Empty column mean lack of data or that a given property is absent. On the basis of data contained in the database a digital standard is created for each polymer. A digital standard is a chain composed of 25 signals with the values of $1,0,-1$. The values of the first 14 signals are the same as the numbers contained in the first 14 columns of the database. The next nine signals (from $15^{\text {th }}$ to $23^{\text {th }}$ ) are used to inform on the number contained in the column № 15, i.e. on the smell of burning polymer. The values of eight signals from among the nine are equal to zero and only one is non-zero and equals 1 . The position of this non-zero signal in the chain may vary from the $15^{\text {th }}$ to $23^{\text {th }}$, indicating the number contained in the column № 15. For instance if this number is equal to 1 , the non-zero signal is at the position 16, if this number is equal to 8 , the non-zero signal is at the position 23 , etc. The last two signals in the chain inform on the limited oxygen index. The signal at the position 24 is equal to 1 if $L O I<21$ or -1 if $21<L O I<28$. If one of these conditions is fulfilled, the signal at the position 25 is equal 0 . In turn if $28<L O I<46$ or $L O I>46$ the signal at the position 25 is equal to 1 or -1 , respectively, and the signal at the position 24 is equal to zero.

All digital standards form a matrix $G=\left[g_{i . j}\right]$ - where $i$ is a consecutive number of a standard, $i=1, \ldots n$, $(n-$ the total amount of standards, $n=22), j-$ position of a signal in a digital standard, $j=1, \ldots, N(N-$ the total number of signals, $N=25)$.

All digital standards constructed for the polymers saved in the data base are shown in Table 2.

\section{Determination of weights}

In the elaborated algorithm the network learns to distinguish a polymer on the basis of its digital standard. The learning involves memorization of the standards, detection of similarities and differences between them and determination of the weights for input signals.

In this work new original algorithm of the weights determination have been proposed. To calculate the weight of a signal at a given position $j$, we calculate how many times the value of signal at this position is equal to 1 in all digital standards and how many times it is equal to -1 . The following equations are used to this aim:

$$
\begin{gathered}
\operatorname{Pos}_{j}=\sum_{i}^{n} g_{i j} \\
N e g_{j}=\sum_{i}^{n}\left|g_{i j}\right|
\end{gathered}
$$

The lower is the sum the more unique is the feature number $j$. When the sum $\operatorname{Pos}_{j}$ or $\mathrm{Neg}_{j}$ equals 1 it means that the considered feature is characteristic for only one standard, so it is particularly important and useful in distinguishing this standard from the remaining ones. For this reason the signal at the position $j$ of the digital standard marked by this feature obtains the highest weight.

When the obtained sums $\mathrm{Pos}_{j}$ or $\mathrm{Neg}_{j}$ are greater than 1 it means that the feature is more popular and the weight of the signal at the position $j$ must be adequately lower.

The sums $\mathrm{Pos}_{j}$ and $\mathrm{Neg}_{j}$ are calculated for signals at all positions $j=1 \ldots N$ of all digital standards $i=1 . . n$.

So, the weight of the $j$-th signal of the $i$-th digital standard is calculated according to the equation: 
T a b l e 2. Digital standards created for polymers from the database

\begin{tabular}{|c|c|c|c|c|c|c|c|c|c|c|c|c|c|c|c|c|c|c|c|c|c|c|c|c|c|}
\hline & \multicolumn{23}{|c|}{ Smell } & \multicolumn{2}{|c|}{ LOI } \\
\hline № & 1 & 2 & 3 & 4 & 5 & 6 & 7 & 8 & 9 & 10 & 11 & 12 & 13 & 14 & 15 & 16 & 17 & 18 & 19 & 20 & 21 & 22 & 23 & 24 & 25 \\
\hline CA & -1 & 1 & 0 & 0 & -1 & 0 & 1 & 1 & 0 & 0 & 0 & 1 & 1 & 0 & 0 & 0 & 0 & 0 & 0 & 0 & 0 & 0 & 1 & 1 & 0 \\
\hline $\mathrm{Ce}$ & 1 & -1 & 1 & 1 & 0 & 0 & 1 & 1 & 0 & 0 & 0 & 0 & 0 & 0 & 1 & 0 & 0 & 0 & 0 & 0 & 0 & 0 & 0 & 1 & 0 \\
\hline Cotton & 1 & 1 & 0 & 0 & 0 & 0 & 0 & 1 & 0 & 1 & 0 & 0 & 0 & 1 & 1 & 0 & 0 & 0 & 0 & 0 & 0 & 0 & 0 & 1 & 0 \\
\hline PA & -1 & -1 & 0 & -1 & -1 & 0 & 1 & -1 & 1 & 0 & 0 & 1 & 1 & 0 & 0 & 1 & 0 & 0 & 0 & 0 & 0 & 0 & 0 & -1 & 0 \\
\hline PAN & 1 & 1 & 1 & 0 & 0 & 0 & 0 & 0 & -1 & 0 & 0 & 0 & 0 & 0 & 0 & 0 & 0 & 0 & 0 & 0 & 0 & 0 & 0 & -1 & 0 \\
\hline PC & 1 & 1 & 1 & 0 & 1 & 0 & -1 & 1 & 1 & 0 & 0 & 1 & -1 & 1 & 0 & 0 & 0 & 0 & 0 & 0 & 1 & 0 & 0 & -1 & 0 \\
\hline PE & 1 & -1 & 1 & -1 & -1 & 0 & 1 & 0 & 0 & 0 & 0 & 0 & 0 & 0 & 0 & 0 & 0 & 0 & 1 & 0 & 0 & 0 & 0 & 1 & 0 \\
\hline PET & -1 & 1 & 0 & 1 & 1 & 0 & 0 & 1 & -1 & -1 & -1 & 0 & 0 & 0 & 0 & 0 & 0 & 1 & 0 & 0 & 0 & 0 & 0 & 1 & 0 \\
\hline PI & 0 & 0 & -1 & 0 & 0 & 0 & 0 & 0 & 0 & 0 & 0 & 0 & 0 & 0 & 0 & 0 & 0 & 0 & 0 & 1 & 0 & 0 & 0 & 0 & 1 \\
\hline PLA & 1 & -1 & 0 & 0 & 0 & 1 & 1 & 0 & 0 & 0 & 0 & 0 & 0 & 0 & 0 & 0 & 0 & 0 & 0 & 0 & 0 & 0 & 0 & 1 & 0 \\
\hline PMMA & 0 & -1 & 0 & 0 & 1 & 0 & -1 & 0 & -1 & 0 & 0 & 1 & 0 & 0 & 0 & 0 & 1 & 0 & 0 & 0 & 0 & 0 & 0 & 1 & 0 \\
\hline POM & 1 & -1 & 0 & 0 & 0 & -1 & 0 & 0 & 0 & 0 & 0 & 0 & 0 & 0 & 0 & 0 & 0 & 0 & 0 & 0 & 0 & 0 & 0 & 1 & 0 \\
\hline PP & 1 & -1 & 1 & -1 & -1 & 0 & 1 & 0 & 0 & 0 & 0 & 0 & 0 & 0 & 0 & 0 & 0 & 0 & 1 & 0 & 0 & 0 & 0 & 1 & 0 \\
\hline PS & 1 & -1 & 1 & 1 & 1 & 0 & -1 & 0 & 0 & -1 & 1 & 0 & 0 & 0 & 0 & 0 & 0 & 1 & 0 & 0 & 0 & 0 & 0 & 1 & 0 \\
\hline PTFE & -1 & 0 & 0 & 0 & 0 & 0 & 0 & 0 & 0 & 1 & 0 & 0 & 0 & 0 & 0 & 0 & 0 & 0 & 0 & 0 & 0 & 0 & 0 & 0 & -1 \\
\hline PU & -1 & -1 & 0 & 1 & -1 & 0 & 1 & 0 & 0 & 1 & 0 & 0 & -1 & 0 & 0 & 0 & 0 & 0 & 0 & 0 & 0 & 1 & 0 & 1 & 0 \\
\hline PVA & 1 & -1 & 0 & 0 & 0 & 0 & 1 & 0 & 0 & 0 & 0 & 0 & 0 & 1 & 0 & 0 & 0 & 0 & 0 & 0 & 0 & 1 & 0 & -1 & 0 \\
\hline PVC & -1 & 1 & 0 & 1 & 1 & 0 & 0 & 1 & -1 & 1 & 1 & 0 & 0 & 1 & 0 & 0 & 0 & 0 & 0 & 1 & 0 & 0 & 0 & 0 & 1 \\
\hline PVDC & -1 & 1 & 0 & 0 & 0 & 0 & 0 & 0 & 0 & 0 & 0 & 0 & 0 & 0 & 0 & 0 & 1 & 0 & 0 & 0 & 0 & 0 & 0 & 0 & 1 \\
\hline PVDF & -1 & -1 & 1 & 0 & 0 & 0 & 1 & 0 & 0 & 0 & 0 & 0 & 0 & 0 & 0 & 0 & 0 & 0 & 0 & 0 & 0 & 1 & 0 & 0 & 1 \\
\hline Silk & -1 & 1 & -1 & 0 & 0 & 0 & 0 & 0 & 0 & 0 & 0 & 1 & 1 & 1 & 0 & 1 & 0 & 0 & 0 & 0 & 0 & 0 & 0 & 1 & 0 \\
\hline WO & -1 & 1 & -1 & -1 & 0 & 0 & 0 & 0 & 0 & -1 & 0 & 0 & 1 & 0 & 0 & 1 & 0 & 0 & 0 & 0 & 0 & 0 & 0 & -1 & 0 \\
\hline
\end{tabular}

$$
w_{i j}=g_{i j} \cdot t_{j}
$$

where

$$
t_{j}= \begin{cases}\left(1-\text { Pos }_{j} / n\right) \cdot g_{i j} & \text { for } \quad g_{i j}=1 \\ \left(1-N e g_{j} / n\right) \cdot g_{i j} & \text { for } \quad g_{i j}=-1\end{cases}
$$

In this way the matrix of weights is constructed: $W=\left[w_{i j}\right]$, where $i$-number of a digital standard, $I=1, \ldots n$, ( $n$ - the total number of standards, $n=22), j-$ position of a signal in a digital standard, $j=1, \ldots, N(N-$ the total number signals, $N=25$ ).

The proposed method of the weights determination and the uniqueness of each digital standard grant the correct identification of polymers on the basis of their flammability.

\section{Recognition of a polymer on the basis of its flammability}

Data on the flammability of a polymer which is to be recognized are saved in the same way and according to the same rules as in the case of the polymers contained in the database. These data are coded by the neural network as signals of the values of $-1,0$ and 1 and saved as a vector $X=\left[x_{j}\right]$ where $j=1, \ldots, N$.
To recognize the unknown polymer on the basis of its flammability an original procedure described below have been developed and implemented into the ANN.

The identification of the polymer consists in comparing of so called total activation signals calculated for each digital standard saved in the data base with the total activation signals calculated for the vector $X$ representing the polymer.

At first, the values of signals located at particular positions of a given digital standard are multiplied by the weights related to these signals, and summed. In this way a set of values describing the total activation $S_{i}$ for the $i$-th digital standard is calculated [11, 12]:

$$
S_{i}=\sum_{j}^{N} g_{i j} w_{i j}
$$

Similarly, the values of signals located at particular positions of the vector $X$ representing the investigated polymer are multiplied by the weights related to these signals, established for particular digital standards, and summed. In this way a set of values describing the total activation $M_{i}$ for the vector $X$ is calculated:

$$
M_{i}=\sum_{j=1}^{N} x_{j} \cdot w_{i j}
$$


$\mathrm{T}$ a b 1 e 3. Results of calculations involved in the recognition process of Ce, PA, PC and POM tested as the unknown polymers which are to be recognized: total activations $S_{\mathrm{i}}$ for the digital standards, total activations $M_{i}$ for the vector $X$ representing the unknown polymer and the degree of similarity $D_{i}$ of a given standard to the unknown polymer

\begin{tabular}{|c|c|c|c|c|c|c|c|c|c|c|c|}
\hline \multirow{3}{*}{ № } & \multirow{3}{*}{ Standard Polymer } & \multirow{3}{*}{ Symbol } & \multirow{3}{*}{$S_{i}$} & \multicolumn{8}{|c|}{ Tested as the unknown polymers } \\
\hline & & & & \multicolumn{2}{|c|}{$\mathrm{Ce}$} & \multicolumn{2}{|c|}{ PA } & \multicolumn{2}{|c|}{ PC } & \multicolumn{2}{|c|}{ POM } \\
\hline & & & & $M_{i}$ & $D_{i}$ & $M_{i}$ & $D_{i}$ & $M_{i}$ & $D_{i}$ & $M_{i}$ & $D_{i}$ \\
\hline 1 & Cellulose acetate & CA & 5.8 & 0.2 & $3 \%$ & 2.2 & $38 \%$ & -0.6 & $-11 \%$ & -1.1 & $-20 \%$ \\
\hline 2 & Cellulose & $\mathrm{Ce}$ & 5.2 & 5.2 & $100 \%$ & -1.5 & $-28 \%$ & 0.4 & $7 \%$ & 1.5 & $30 \%$ \\
\hline 3 & Cotton & $\mathrm{CO}$ & 4.9 & 2.1 & $43 \%$ & -2.4 & $-49 \%$ & 2.1 & $44 \%$ & 0.5 & $9 \%$ \\
\hline 4 & Polyamide & PA & 8.4 & -2.1 & $-25 \%$ & 8.4 & $100 \%$ & -1.8 & $-21 \%$ & -0.8 & $-10 \%$ \\
\hline 5 & Polyacrylonitrile & PAN & 3.4 & -0.1 & $-4 \%$ & -1.2 & $-35 \%$ & 1.8 & $52 \%$ & -0.8 & $-24 \%$ \\
\hline 6 & Polycarbonate & PC & 9.3 & -0.3 & $-3 \%$ & -2.0 & $-21 \%$ & 9.3 & $100 \%$ & -0.8 & $-9 \%$ \\
\hline 7 & Polyethylene & PE & 4.5 & 2.8 & $63 \%$ & 0.8 & $18 \%$ & -1.1 & $-25 \%$ & 1.5 & $34 \%$ \\
\hline 8 & $\begin{array}{l}\text { Poly(ethylene } \\
\text { terephthalate) }\end{array}$ & PET & 7.5 & 0.9 & $12 \%$ & -3.6 & $-48 \%$ & 0.2 & $3 \%$ & -0.6 & $-8 \%$ \\
\hline 9 & Polyimide & PI & 2.6 & -0.9 & $-33 \%$ & 0.0 & $0 \%$ & -0.9 & $-33 \%$ & 0.0 & $0 \%$ \\
\hline 10 & Polylactide & PLA & 3.1 & 2.1 & $68 \%$ & 0.0 & $1 \%$ & -1.0 & $-33 \%$ & 0.5 & $17 \%$ \\
\hline 11 & $\begin{array}{l}\text { Poly(methyl } \\
\text { methacrylate) }\end{array}$ & PMMA & 5.1 & 0.1 & $3 \%$ & -1.7 & $-33 \%$ & 0.6 & $12 \%$ & 1.0 & $19 \%$ \\
\hline 12 & Polyoxymethylene & POM & 2.5 & 1.5 & $61 \%$ & -0.5 & $-21 \%$ & -0.5 & $-18 \%$ & 2.5 & $100 \%$ \\
\hline 13 & Polypropylene & PP & 5.4 & 2.0 & $36 \%$ & 1.7 & $31 \%$ & -1.1 & $-21 \%$ & 1.5 & $29 \%$ \\
\hline 14 & Polystyrene & PS & 7.3 & 2.1 & $29 \%$ & -3.0 & $-40 \%$ & 1.9 & $25 \%$ & 1.5 & $21 \%$ \\
\hline 15 & Polytetrafluoroethylene & PTFE & 2.4 & -0.5 & $-23 \%$ & 0.5 & $23 \%$ & -0.5 & $-23 \%$ & -0.5 & $-23 \%$ \\
\hline 16 & Polyurethane & PU & 6.3 & 1.8 & $29 \%$ & 0.2 & $4 \%$ & -2.0 & $-32 \%$ & 0.5 & $7 \%$ \\
\hline 17 & Poly(vinyl alcohol) & PVA & 4.0 & 0.9 & $21 \%$ & 1.3 & $33 \%$ & 1.0 & $25 \%$ & 0.3 & $7 \%$ \\
\hline 18 & Poly(vinyl chloride) & PVC & 8.5 & 0.4 & $4 \%$ & -3.1 & $-37 \%$ & 1.5 & $18 \%$ & -1.1 & $-13 \%$ \\
\hline 19 & Polyvinylidene chloride & PVDC & 2.0 & -1.1 & $-56 \%$ & 0.0 & $-2 \%$ & 0.0 & $2 \%$ & -1.1 & $-56 \%$ \\
\hline 20 & $\begin{array}{l}\text { Poly(vinylidene } \\
\text { fluoride) }\end{array}$ & PVDF & 4.0 & 1.2 & $30 \%$ & 1.6 & $40 \%$ & -1.0 & $-24 \%$ & 0.0 & $-1 \%$ \\
\hline 21 & Silk & Silk & 5.7 & -1.5 & $-26 \%$ & 1.9 & $33 \%$ & -0.6 & $-10 \%$ & -0.6 & $-11 \%$ \\
\hline 22 & Wool & WO & 6.2 & -3.6 & $-59 \%$ & 3.3 & $53 \%$ & -0.9 & $-14 \%$ & -1.9 & $-31 \%$ \\
\hline
\end{tabular}

The similarity of the burning behavior of the unknown polymer to the behavior of a given polymer $i$ from the data base is measured by the ratio of the sums $M_{i}$ and $S_{i}$ :

$$
R_{i}=M_{i} / S_{i}
$$

for $i=1 \ldots . n$, where $n-$ total number of standard curves.

The digital standard $i$ and the respective polymer, for which the ratio $R_{i}$ is the highest and simultaneously $R_{i}>0$, is chosen by the network as the most similar to the investigated polymer. In such a case, the network informs that a polymer has been found in the data base, the burning behavior of which is similar to the behavior of the unknown polymer with the degree of similarity $D_{i}$

$$
D_{i}=R_{i} \cdot 100 \%
$$

If for all digital standards $R_{i}<0$ it means that the burning properties of the investigated polymer are dissimilar to the properties of all standard polymers in the data base. The network informs that the unknown polymer hasn't been identified.

\section{Testing of the algorithm}

The algorithm has been used for identification of various polymers on the basis of three types of data on their flammability. At first the polymers were identified using exactly the same sets of data as those coded in the database in digital standards. Next test consisted in the identification of chosen polymers when the set of their flammability data was incomplete. In the third test, the data of LOI of tested polymers were omitted. 
$\mathrm{T}$ a b 1 e 4. Results of calculations involved in the recognition process of chosen polymers when one of their individual properties was omitted: total activations $S_{i}$ for the digital standards, total activations $M_{i}$ for the vector $X$ representing the unknown polymer and the degree of similarity $D_{i}$ of a given standard to the unknown polymer

\begin{tabular}{|c|c|c|c|c|c|c|c|c|c|c|}
\hline \multirow{5}{*}{ № } & \multirow{5}{*}{ Standard Polymer } & \multirow{5}{*}{ Symbol } & \multicolumn{8}{|c|}{ Tested as the unknown polymers } \\
\hline & & & CA & PA & PE & PMMA & PC & PI & PS & PVA \\
\hline & & & \multicolumn{8}{|c|}{ Number of omitted property } \\
\hline & & & 1 & 1 & 2 & 9 & 15 & 15 & 10 & 14 \\
\hline & & & $D_{i}$ & $D_{i}$ & $D_{i}$ & $D_{i}$ & $D_{i}$ & $D_{i}$ & $D_{i}$ & $D_{i}$ \\
\hline 1 & Cellulose acetate & CA & $91 \%$ & $28 \%$ & $14 \%$ & $-20 \%$ & $-11 \%$ & $0 \%$ & $-43 \%$ & $-9 \%$ \\
\hline 2 & Cellulose & $\mathrm{Ce}$ & $16 \%$ & $-17 \%$ & $30 \%$ & $8 \%$ & $7 \%$ & $-13 \%$ & $46 \%$ & $22 \%$ \\
\hline 3 & Cotton & $\mathrm{CO}$ & $27 \%$ & $-37 \%$ & $21 \%$ & $-2 \%$ & $44 \%$ & $0 \%$ & $9 \%$ & $-11 \%$ \\
\hline 4 & Polyamide & PA & $17 \%$ & $94 \%$ & $10 \%$ & $-10 \%$ & $-21 \%$ & $0 \%$ & $-36 \%$ & $16 \%$ \\
\hline 5 & Polyacrylonitrile & PAN & $17 \%$ & $-19 \%$ & $13 \%$ & $-40 \%$ & $52 \%$ & $-20 \%$ & $-4 \%$ & $21 \%$ \\
\hline 6 & Polycarbonate & PC & $-5 \%$ & $-15 \%$ & $-13 \%$ & $11 \%$ & $89 \%$ & $-7 \%$ & $16 \%$ & $-1 \%$ \\
\hline 7 & Polyethylene & PE & $19 \%$ & $30 \%$ & $91 \%$ & $-8 \%$ & $-25 \%$ & $-15 \%$ & $19 \%$ & $25 \%$ \\
\hline 8 & $\begin{array}{l}\text { Poly(ethylene } \\
\text { terephthalate) }\end{array}$ & PET & $7 \%$ & $-56 \%$ & $-21 \%$ & $9 \%$ & $3 \%$ & $0 \%$ & $11 \%$ & $-22 \%$ \\
\hline 9 & Polyimide & PI & $0 \%$ & $0 \%$ & $-33 \%$ & $0 \%$ & $-33 \%$ & $66 \%$ & $-33 \%$ & $0 \%$ \\
\hline 10 & Polylactide & PLA & $3 \%$ & $19 \%$ & $52 \%$ & $13 \%$ & $-33 \%$ & $0 \%$ & $30 \%$ & $36 \%$ \\
\hline 11 & $\begin{array}{l}\text { Poly(methyl } \\
\text { methacrylate) }\end{array}$ & PMMA & $-27 \%$ & $-33 \%$ & $-22 \%$ & $84 \%$ & $12 \%$ & $0 \%$ & $51 \%$ & $-17 \%$ \\
\hline 12 & Polyoxymethylene & POM & $-20 \%$ & $0 \%$ & $41 \%$ & $39 \%$ & $-18 \%$ & $0 \%$ & $61 \%$ & $21 \%$ \\
\hline 13 & Polypropylene & PP & $16 \%$ & $42 \%$ & $91 \%$ & $-7 \%$ & $-21 \%$ & $-13 \%$ & $0 \%$ & $21 \%$ \\
\hline 14 & Polystyrene & PS & $-29 \%$ & $-33 \%$ & $-9 \%$ & $36 \%$ & $25 \%$ & $-9 \%$ & $88 \%$ & $-4 \%$ \\
\hline 15 & $\begin{array}{l}\text { Polytetrafluo- } \\
\text { roethylene }\end{array}$ & PTFE & $0 \%$ & $0 \%$ & $-23 \%$ & $0 \%$ & $-23 \%$ & $-42 \%$ & $-23 \%$ & $-23 \%$ \\
\hline 16 & Polyurethane & PU & $-1 \%$ & $-5 \%$ & $9 \%$ & $-6 \%$ & $-32 \%$ & $0 \%$ & $-2 \%$ & $14 \%$ \\
\hline 17 & Poly(vinyl alcohol) & PVA & $2 \%$ & $46 \%$ & $9 \%$ & $-21 \%$ & $25 \%$ & $0 \%$ & $-8 \%$ & $81 \%$ \\
\hline 18 & $\begin{array}{l}\text { Poly(vinyl } \\
\text { chloride) }\end{array}$ & PVC & $6 \%$ & $-43 \%$ & $-25 \%$ & $2 \%$ & $18 \%$ & $10 \%$ & $16 \%$ & $-13 \%$ \\
\hline 19 & $\begin{array}{l}\text { Poly(vinylidene } \\
\text { chloride) }\end{array}$ & PVDC & $29 \%$ & $-29 \%$ & $-27 \%$ & $16 \%$ & $2 \%$ & $0 \%$ & $-56 \%$ & $-56 \%$ \\
\hline 20 & $\begin{array}{l}\text { Poly(vinylidene } \\
\text { fluoride) }\end{array}$ & PVDF & $2 \%$ & $27 \%$ & $18 \%$ & $-2 \%$ & $-24 \%$ & $4 \%$ & $1 \%$ & $35 \%$ \\
\hline 21 & Silk & Silk & $38 \%$ & $24 \%$ & $-16 \%$ & $12 \%$ & $-10 \%$ & $15 \%$ & $-26 \%$ & $-29 \%$ \\
\hline 22 & Wool & WO & $23 \%$ & $44 \%$ & $-22 \%$ & $-22 \%$ & $-14 \%$ & $14 \%$ & $-59 \%$ & $-6 \%$ \\
\hline
\end{tabular}

The results of calculations involved in the recognition process are collected in the Table 3.

A comparison of the values of $S_{i}$ obtained for all digital standards and of $M_{i}$ calculated_for PC (polycarbonate) tested as an unknown polymer which is to be recognized, is shown in Fig. 1. As it is seen, for PC the values of $M_{i}$ and $S_{i}$ are exactly the same. The plot shows that if some properties of the burning process were omitted, the network would indicate other polymers for which $S_{i}$ is close to $M_{i^{\prime}}$ like cotton or PVC.
As on can see in the Table 3, also the remaining polymers: $\mathrm{Ce}, \mathrm{PA}$ and POM tested as the unknown ones have been correctly identified obtaining the degree of similarity $D_{i}$ to their standards equal to $100 \%$.

Table 4 presents the values of the degree of similarity $D_{i}$ calculated by the network when individual properties were omitted. The omission of one property does not influenced negatively on the result of recognising.

The algorithm was also so tested when 2 or more properties were omitted. It was stated that the network gave 
$\mathrm{T}$ a b 1 e 5. Results of calculations involved in the recognition process of chosen polymers when the information on the $L O I$ of an unknown polymer was omitted: total activations $S_{i}$ for the digital standards, total activations $M_{i}$ for the vector $X$ representing the unknown polymer and the degree of similarity $D_{i}$ of a given standard to the unknown polymer

\begin{tabular}{|c|c|c|c|c|c|c|c|c|c|c|}
\hline \multirow{3}{*}{ № } & \multirow{3}{*}{ Standard Polymer } & \multirow{3}{*}{ Symbol } & \multicolumn{8}{|c|}{ Tested as the unknown polymers } \\
\hline & & & CA & PA & PAN & PC & POM & PVA & PTFE & WO \\
\hline & & & $D_{i}$ & $D_{i}$ & $D_{i}$ & $D_{i}$ & $D_{i}$ & $D_{i}$ & $D_{i}$ & $D_{i}$ \\
\hline 1 & Cellulose acetate & CA & $92 \%$ & $38 \%$ & $1 \%$ & $-11 \%$ & $-20 \%$ & $-9 \%$ & $9 \%$ & $31 \%$ \\
\hline 2 & Cellulose & $\mathrm{Ce}$ & $5 \%$ & $-18 \%$ & $14 \%$ & $17 \%$ & $20 \%$ & $31 \%$ & $-10 \%$ & $-48 \%$ \\
\hline 3 & Cotton & $\mathrm{CO}$ & $16 \%$ & $-38 \%$ & $23 \%$ & $54 \%$ & $-1 \%$ & $15 \%$ & $6 \%$ & $-16 \%$ \\
\hline 4 & Polyamide & PA & $24 \%$ & $91 \%$ & $-23 \%$ & $-30 \%$ & $-1 \%$ & $6 \%$ & $6 \%$ & $30 \%$ \\
\hline 5 & Polyacrylonitrile & PAN & $1 \%$ & $-57 \%$ & $77 \%$ & $29 \%$ & $-1 \%$ & $-1 \%$ & $-16 \%$ & $-19 \%$ \\
\hline 6 & Polycarbonate & PC & $-11 \%$ & $-29 \%$ & $10 \%$ & $92 \%$ & $0 \%$ & $-1 \%$ & $-6 \%$ & $-17 \%$ \\
\hline 7 & Polyethylene & PE & $6 \%$ & $29 \%$ & $14 \%$ & $-14 \%$ & $23 \%$ & $36 \%$ & $-12 \%$ & $-17 \%$ \\
\hline 8 & $\begin{array}{l}\text { Poly(ethylene } \\
\text { terephthalate) }\end{array}$ & PET & $15 \%$ & $-42 \%$ & $12 \%$ & $10 \%$ & $-15 \%$ & $-15 \%$ & $-4 \%$ & $16 \%$ \\
\hline 9 & Polyimide & PI & $0 \%$ & $0 \%$ & $-33 \%$ & $-33 \%$ & $0 \%$ & $0 \%$ & $0 \%$ & $33 \%$ \\
\hline 10 & Polylactide & PLA & $-14 \%$ & $17 \%$ & $1 \%$ & $-17 \%$ & $1 \%$ & $52 \%$ & $-17 \%$ & $-33 \%$ \\
\hline 11 & $\begin{array}{l}\text { Poly(methyl } \\
\text { methacrylate) }\end{array}$ & PMMA & $-27 \%$ & $-23 \%$ & $6 \%$ & $21 \%$ & $10 \%$ & $-7 \%$ & $0 \%$ & $-10 \%$ \\
\hline 12 & Polyoxymethylene & POM & $-41 \%$ & $-2 \%$ & $2 \%$ & $2 \%$ & $80 \%$ & $41 \%$ & $-21 \%$ & $-41 \%$ \\
\hline 13 & Polypropylene & PP & $6 \%$ & $41 \%$ & $14 \%$ & $-12 \%$ & $19 \%$ & $31 \%$ & $-10 \%$ & $-17 \%$ \\
\hline 14 & Polystyrene & PS & $-37 \%$ & $-34 \%$ & $10 \%$ & $32 \%$ & $14 \%$ & $2 \%$ & $-19 \%$ & $-22 \%$ \\
\hline 15 & $\begin{array}{l}\text { Polytetrafluo- } \\
\text { roethylene }\end{array}$ & PTFE & $23 \%$ & $23 \%$ & $-23 \%$ & $-23 \%$ & $-23 \%$ & $-23 \%$ & $58 \%$ & $-12 \%$ \\
\hline 16 & Polyurethane & PU & $8 \%$ & $12 \%$ & $-17 \%$ & $-24 \%$ & $-1 \%$ & $22 \%$ & $22 \%$ & $-39 \%$ \\
\hline 17 & Poly(vinyl alcohol) & PVA & $-11 \%$ & $13 \%$ & $1 \%$ & $6 \%$ & $26 \%$ & $81 \%$ & $-13 \%$ & $-26 \%$ \\
\hline 18 & $\begin{array}{l}\text { Poly(vinyl } \\
\text { chloride) }\end{array}$ & PVC & $13 \%$ & $-37 \%$ & $10 \%$ & $18 \%$ & $-13 \%$ & $-4 \%$ & $16 \%$ & $-5 \%$ \\
\hline 19 & $\begin{array}{l}\text { Poly(vinylidene } \\
\text { chloride) }\end{array}$ & PVDC & $56 \%$ & $-2 \%$ & $2 \%$ & $2 \%$ & $-56 \%$ & $-56 \%$ & $27 \%$ & $56 \%$ \\
\hline 20 & $\begin{array}{l}\text { Poly(vinylidene } \\
\text { fluoride) }\end{array}$ & PVDF & $16 \%$ & $40 \%$ & $-9 \%$ & $-24 \%$ & $-1 \%$ & $35 \%$ & $13 \%$ & $-16 \%$ \\
\hline 21 & Silk & Silk & $48 \%$ & $42 \%$ & $-14 \%$ & $-2 \%$ & $-20 \%$ & $-6 \%$ & $10 \%$ & $64 \%$ \\
\hline 22 & Wool & WO & $32 \%$ & $40 \%$ & $-13 \%$ & $-26 \%$ & $-18 \%$ & $-18 \%$ & $-5 \%$ & $87 \%$ \\
\hline
\end{tabular}

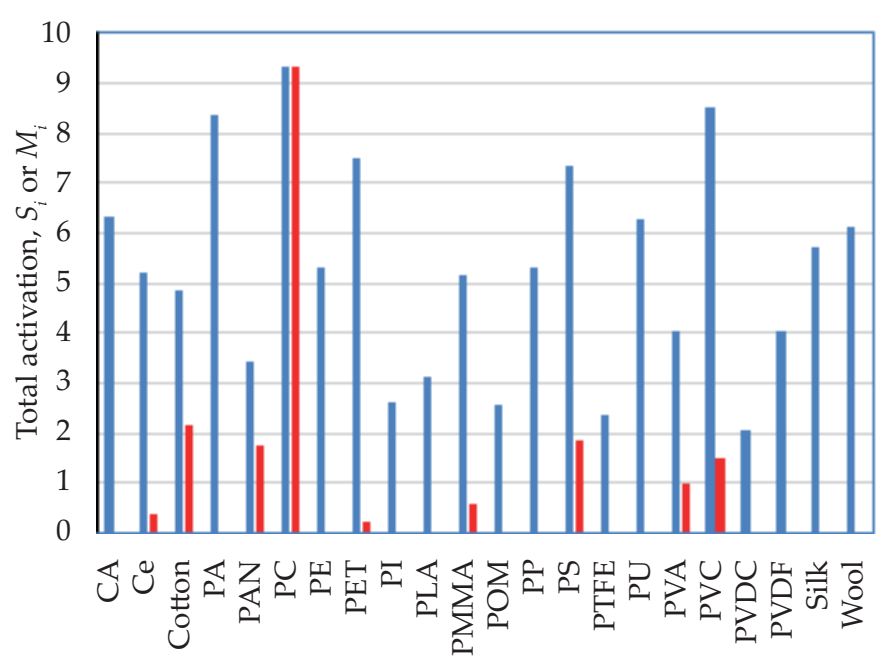

Fig. 1. The values of the total activations $S_{i}$ (blue) and $M_{i}$ (red) obtained for PC tested as an unknown polymer more wrong solutions in such cases, particularly when the weights related to the omitted properties were relatively high.

Table 5 presents the results of tests in which the information on the LOI of an unknown polymer was omitted. Obtained results shows that in such cases the values of the degree of similarity $D_{i}$ are usually lower but all the less, the network properly recognizes the unknown polymer.

However, when apart from LOI some other flammability property is also omitted, the network does not recognize the polymer.

\section{SUMMARY}

The effectivity of presented neural network is very high. The data obtained in flammability tests combined with the limited oxygen index allow for almost faultless 
identification of a polymer even if not all characteristic properties of its burning process are noticed and introduced into the network. Obviously, the algorithm is not able to differentiate between the polymers with the same flammability data in the database, e.g. polyethylene (PE) and polypropylene (PP). Their burning properties and oxygen indices are exactly the same. Some additional methods like Near Infrared spectroscopy or X-ray diffraction should be used to distinguish between these two polymers. Unfortunately, the recognition of a polymer solely on the basis of its $L O I$ is practically impossible because for several polymers the value of this parameter is the same or very close to each other. However, when some burning properties of a polymer are omitted, the $L O I$ is very helpful in a correct identification.

It should be emphasized that the elaborated artificial neural network is an universal algorithms because it can work effectively using digital standards created on the basis of various properties of investigated materials which can be coded in similar way as data on their flammability.

The network described in this work has been elaborated as a separate computer program using the Object Pascal programming language. However the developed algorithms can be easily implemented in MS EXCEL spreadsheet by means of Visual Basic for Application programming language.

\section{REFERENCES}

[1] Jankowska G., Przygocki W., Włochowicz A.: "Palność polimerów i materiałów polimerowych", WNT, Warszawa 2007.
[2] Jurkowski B., Jurkowska B., Rydarowski H.: „Palność materiałów polimerowych”, Wydawnictwo Politechniki Poznańskiej, Poznań 2010.

[3] Rabek J.F.: „Współczesna wiedza o polimerach”, PWN, Warszawa 2016.

[4] Iwko J.: Tworzywa sztuczne i chemia 2009, 3, 46.

[5] Półka M.: „Badanie palności metodą wskaźnika tlenowego", SGSP, Warszawa 1996.

[6] PN-EN ISO 4589-2:2006: Tworzywa sztuczne Oznaczanie zapalności metodą wskaźnika tlenowego - Część 2: Badanie w temperaturze pokojowej.

[7] Vapnik V.N.: "Statistical Learning Theory", Wiley, New York 1998.

[8] Egmont-Petersen M., de Ridder D., Handels H.: Pattern Recognition 2002, 35 (10), 2279. http://dx.doi.org/10.1016/S0031-3203(01)00178-9

[9] Bengio Y., Courville A., Goodfellow I.: "Deep Learning", PWN SA, Warszawa 2018.

[10] Murata N., Yoshizawa S., Amari S.: IEEE Trans. Neural Networks 1994, 5 (6), 865.

[11] Ogiela M., Tadeusiewicz R.: Pattern Recognition 2003, 36, 2441. https://doi.org/10.1016/S0031-3203(03)00089-X

[12] Rutkowski L.: „Metody i techniki sztucznej inteligencji", PWN, Warszawa 2005.

[13] Skowron M., Wolkiewicz M., Orłowska-Kowalska T., Kowalski C.: Applied Sciences 2019, 9 (4), art. 616.

[14] Skowron M., Wolkiewicz M., Orłowska-Kowalska T., Kowalski T.: Energies 2019, 129 (12), art. 2392.

[15] Garbarski J., Fabijański M.: Problemy Kolejnictwa 2012, $154,47$.

Received 5 III 2020. 